\title{
Thermal and behavioral response of horses submitted to functional exercises and acupuncture
}

\author{
Paula Gomes Rodrigues ${ }^{1 *}$ Luana Moura Delmondes Freitas ${ }^{1}(\mathbb{D})$ Katia de Oliveira $^{2}$ \\ Carlos Otávio Damas Martins ${ }^{1}$ (i) Camilla Mendonça Silva ${ }^{1}$ (i) Clístenes Gomes de Oliveira ${ }^{1}$ (1) \\ José Wellington Rodrigues Lima Júnior ${ }^{1}$ (1) Jonatan Mikhail Del Solar Velarde ${ }^{1}$ (i)
}

'Universidade Federal de Sergipe (UFS), 49100-000, São Cristóvão, SE, Brasil. E-mail: paulagrodrigues@hotmail.com. *Corresponding author. ${ }^{2}$ Universidade Estadual Paulista (UNESP), Dracena, SP, Brasil.

\begin{abstract}
The present research evaluated muscle activation degrees and relaxation of patrolling horses submitted to dynamic mobilization exercises, associated or not with acupuncture. Twelve mixed breed gelding, aged $10 \pm 2.0$ years, were distributed in three treatments. Treatment with a single session of dynamic mobilization exercises (longitudinal cervical flexion of head between hooves, between carpus and to up to chest); treatment with a single acupuncture session during 20 minutes, and treatment with a single session of dynamic mobilization exercises with acupuncture. Thermographic images were analyzed before and after applying treatments to the cervical, thoracic, dorsal, abdominal and pelvic regions. Animal behavior was assessed through five minutes filming, before and ten minutes after the end of each treatment application, in an uninterrupted way. Increase in animals body temperature at the end of the single session of functional exercises $(P<0.0001)$ at all animal regions were reported, being cervical and thoracic areas with highest final temperature values. There was no temperature variation for other treatments $(P>0.05)$. All treatments stimulated higher expression frequency $(P<0.05)$ of relaxation behaviors. A single dynamic mobilization exercises session is enough to promote intense muscular response in entire horse body; and with acupuncture, individually or associated, promoted muscle and mental relaxation, interfering positively in animal welfare.
\end{abstract}

Key words: acupoints, ethology, dynamic mobilization, relaxation, thermography.

Resposta térmica e comportamental de equinos submetidos a exercícios funcionais e acupuntura

RESUMO: Objetivou-se avaliar o grau de ativação e relaxamento muscular de equinos de patrulhamento submetidos à exercícios de mobilização dinâmica associados ou não à acupuntura. Doze cavalos castrados, sem raça definida, com idade de $10 \pm 2,0$ anos, foram distribuídos em três tratamentos: tratamento com uma sessão única de exercícios de mobilização dinâmica (flexão cervical longitudinal da cabeça entre os cascos, entre os carpos e até o peito); tratamento com sessão única de acupuntura (20 minutos); e tratamento com sessão única composta por exercícios de mobilização dinâmica associados a acupuntura. Foram analisadas imagens termográficas antes e após a aplicação dos tratamentos das regiões cervical, torácica, dorsal, abdominal e pélvica. A avaliação comportamental foi obtida por meio de filmagens 5 minutos antes e 10 minutos após o término da aplicação dos tratamentos, de maneira ininterrupta. Houve aumento (P < 0,0001) na temperatura corporal dos animais ao final da sessão única de exercícios funcionais para todas as regiões estudadas, sendo a cervical e torácica aquelas com maior valor de temperatura final. Não houve variação da temperatura nos demais tratamentos $(P>0,05)$. Todos os tratamentos geraram maior frequência $(P<0,05)$ na expressão de comportamentos relacionados ao relaxamento. A realização de uma sessão única de exercícios de mobilização dinâmica é suficiente para promover uma intensa resposta muscular em todo o corpo do equino, e tanto os exercícios funcionais quanto a acupuntura, de maneira individual ou associada, foram capazes de promover relaxamento muscular e mental, interferindo de maneira positiva no bem-estar dos animais.

Palavras-chave: acupontos, etologia, mobilização dinâmica, relaxamento, termografia.

\section{INTRODUCTION}

The increased interest in leisure activities, sports and equestrian therapies resulted in high exposure of horses to intense training and, when done inappropriately, with higher frequency than their physical capacity (RIZZO et al., 2017). This fact can support musculoskeletal disorders appearance as severe muscle pain, joints injuries, tendons and ligaments (ROPKA-MOLIK et al.,
2017). In addition, aiming to reduce athletic performance, these problems also cause high degree of stereotyping, impairing animal well-being and life quality (DYSON et al., 2018).

Therefore, techniques that promote musculature strengthening in horses, such as functional exercises practice, have been extensively studied in recent years (RODRIGUES et al., 2021; OLIVEIRA et al., 2020), since they deal with non-invasive procedures aiming to prevent and 
rehabilitate horses, in cases of skeletal muscle injuries (OLIVEIRA et al., 2015; CLAYTON, 2016), promote muscle hypertrophy (D 'ANGELIS et al., 2005; STUBBS et al ., 2011; TABOR, 2015) and improve gait quality and athletic performance (CLAYTON et al., 2011).

Functional exercises practice is based on a targeted exercise set execution, using the animal's own body, in order to stimulate and strengthen several muscle groups; developing animal balance, motor coordination, elasticity, strength and concentration (OLIVEIRA et al., 2015). In addition, due to its ability to reduce muscle tension, functional exercises can also promote animal relaxation and; consequently, improve well-being (CLAYTON et al., 2010; RODRIGUES et al., 2021).

Another technique focusing to reduce muscle tension and pain in athletes and work animals, is acupuncture (RIZZO et al., 2017; PELLEGRINI et al., 2018). According to Le Jeune (2016), acupuncture can reduce pain, in cervical region and those resulting from acute or chronic laminitis with degree of lameness reduction, proving positive effects on animal welfare. Chronic pain, and muscular and skeletal disorders at lumbar region of equine athletes can also be reduced through acupuncture, as found by ALJOBORY (2017).

Thus, in order to evaluate innovative methods capable of promoting muscle strengthening and; consequently, prevent or even solve problems related to musculoskeletal disorders in athletes and work horses, the present study determined the occurrence of muscle activation and relaxation of working horses submitted to dynamic mobilization exercises, associated or not to acupuncture.

\section{MATERIALS AND METHODS}

\section{Experimental design}

The experiment was developed at the Mounted Police Squadron (EPMon) in Aracaju/ Sergipe. Twelve healthy mixed breed gelding, with 10 \pm 2 years old and body weight around $450.0 \pm 30.0 \mathrm{~kg}$, were used. The horses execute step patrolling work, with three alternating days a week and in two periods: morning and night, where each period corresponded to six hours of walking patrol work.

The experimental design adopted here was longitudinal, in which the application of the three functional exercise programs, combined or not combined with acupuncture, were evaluated, with measures repeated over time. The treatments were applied inside the pens $\left(16 \mathrm{~m}^{2}\right)$ where the animals were routinely housed. Treatment 1 (n $=$ 12 animals) consisted of a session of functional dynamic mobilization exercises; treatment $2(n=12$ animals) consisted of an acupuncture session during 20 minutes; finally, treatment 3 ( $n=12$ animals) consisted of a combination of functional dynamic mobilization exercises immediately followed by an acupuncture session. All animals were submitted to all treatments.

Three functional dynamic mobilization exercises were selected (STUBBS et al., 2011; OLIVEIRA et al., 2020) to compose the experimental treatments, adopting the following sequence (Figure 1):

Exercise 1: Head-chest longitudinal cervical flexion: head ventral displacement towards manubrium region (Figure 1A);

Exercise 2: Head-carpal longitudinal cervical flexion: head ventral displacement until its complete position between thoracic limbs and carpal area (Figure 1B);

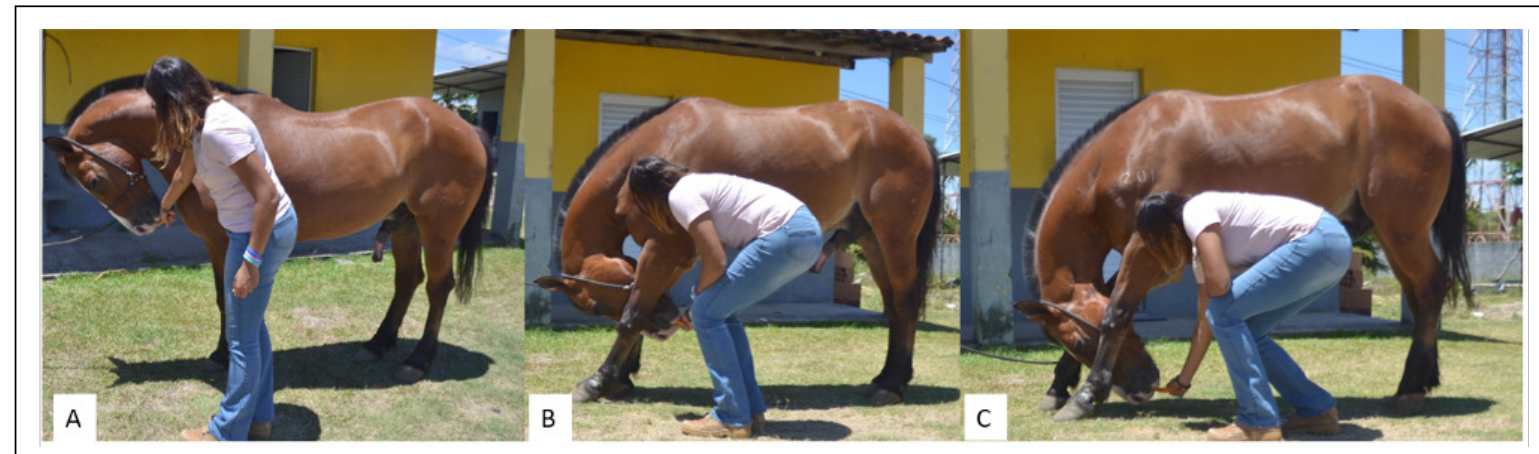

Figure 1 - Longitudinal Cervical flexion head to chest (1A); Longitudinal Cervical flexion head between the carpus (1B); Longitudinal Cervical flexion head between hooves (1C). 
Exercise 3: Longitudinal cervical flexion head-hooves: head ventral displacement until its complete positioning between thoracic limbs and hooves area (Figure 1C).

The functional exercises were performed continuously with no interval between each one, adopting five repetitions for each exercise, with five seconds of each repetition (CLAYTON et al., 2010). These exercises were performed by the same person previously trained, on flat surface and with the horse hold by halter. To encourage the animal to perform the exercises, and maintain the requested position during the stipulated time, carrots were used as snack (OLIVEIRA et al., 2020).

To perform acupuncture, acupoints were selected corresponding to the same anatomical regions worked by the functional exercises. Hence, acupoints at cervical region (VB20, VB21, VG14, B10 e B11), thoracic (B16, B18, B20, VG12) and lumbar (VG 3 , VG 4 and BaiHui) were stimulated according techniques described by Xie \& Preast (2011). For stimulation of each acupoint, sterile needles $(0.20 \mathrm{~mm}$ $\mathrm{X} 40 \mathrm{~mm}$, DongBang $\left.{ }^{\circledR}\right)$ were inserted superficially on epidermis region, where they remained for 20 minutes (LE JEUNE et al., 2016).

\section{Data Collection}

Muscle activation was assessed by thermographic images from a digital thermographic camera (FLIR ${ }^{\circledR}$, model T640Sc), with measurement ranging between $-40{ }^{\circ} \mathrm{C}$ to $2,000^{\circ} \mathrm{C}$ and precision of $+/-1{ }^{\circ} \mathrm{C}$. The images were collected before and after experimental treatments. Before the beginning of treatments, all animals were filmed for two minutes uninterrupted to collect temperature values every 30 seconds, totaling five observations regarding the animals' initial skin surface temperature. After the end of the exercises, a filming was performed with duration of five uninterrupted minutes, to collect temperature data collected every 30 seconds, totaling 11 observations.

For thermographic images collection of cervical, thoracic, dorsal, abdominal and pelvic regions of horses' bodies, the horses were kept inside stalls without direct sunlight or wind. The stalls used were those where the animals are routinely housed; to be specific, where animals are already adapted (SOROKO et al., 2019). Animals were not washed or submitted to previous hair brushing, avoiding surface skin temperature variations (MONTANHOLI et al., 2008).

Once the thermographic images were collected, light emissivity was calculated using the black non-reflective tape, adhered to the dorsal region of the animals immediately before the start of thermographic filming, simulating black a body condition, whose emissivity is equal to 1 . Therefore, the emissivity adopted in this study was 0.8 . The images obtained were; subsequently, evaluated for temperature and emissivity using Flir Tools + , thermographic camera's software, following methodologies proposed by FREIRE et al. (2015).

To determine animal relaxation degree, behavioral analysis was applied using video recording images (GoPro ${ }^{\circledR}$ digital camera). The camera was positioned on the bay wall and the animals were previously adapted to camera presence. Videos were recorded for five uninterrupted minutes before the beginning of experimental treatments application and, immediately after these, for ten minutes. Thus, two video recordings for each animal in each treatment were registered (GLEERUP et al., 2015).

Subsequently, the videos were used to register punctual behavioral analysis, every 30 seconds of filming the video was paused and the behavior that the animal was showing at that time was noted (GLEERUP et al., 2015). Thus, 30 observations were made, with 10 behavioral assessments before and 20 after experimental treatments application.

Behavioral patterns related to equine relaxation were evaluated, which are: chewing, penis exposure, ears positioned laterally (drooped ears), standing on three limbs, lowering neck, dozing, snorting and pummeling/shaking the body (DYSON et al., 2018).

\section{Statistical analysis}

The SAS statistical program (version 9.3) was used for data analysis, with a linear additive model and with $5 \%$ of statistical significance. To assess treatments influence on behavior and body temperature, analysis of variance (ANOVA) was performed for parametric (temperature) and nonparametric (behavior) data.

Parametric data, considering as repeated measures over time, were analyzed using the PROC GLIMMIX package; therefore, when significance was reported $(\mathrm{P}<0.05)$, arithmetic means were compared using Tukey test. Non-parametric data were applied using the PROC NPAR1WAY package with KruskalWallis Test; therefore, when significance were found $(\mathrm{P}<0.05)$, medians related to independent variables were compared using Dwass, Steel, CritchlowFligner multiple comparison procedure, which is based on pairwise two-sample rankings.

Ciência Rural, v.52, n.2, 2022. 


\section{RESULTS}

Body surface temperature showed a significant increase $(\mathrm{P}<0.0001)$ five minutes after performing the exercises, when compared to the initial body temperature (Table 1). However, this difference was not observed in treatments containing the combination of functional exercises and acupuncture $(\mathrm{P}=0.5875)$ or only acupuncture $(\mathrm{P}=0.8403)$.

On functional exercises treatment, no peak temperature was detected during the five minutes evaluation $(\mathrm{P}>0.05)$. This accuse that the temperature increased on first minute of evaluation immediately after finishing physical activity, and remained constantly, on same temperature, until the end of the evaluation, showing that more prolonged analysis is necessary, to detect the exact moment when temperature drops, reducing muscle activation.

All five animal regions showed increase $(\mathrm{P}<0.05)$ in temperature after completing a single session of functional exercises (Table 2). However, in the case of animals submitted to the combination of functional exercises and acupuncture, only cervical region showed increase in muscle temperature, even after the end of the treatment application. Animals submitted to acupuncture, conversely, did not manifest body temperature change in cervical, thoracic, abdominal, dorsal and pelvic regions, before and after the end of treatment (Table 2).

Horses in all treatments showed frequency increase of relaxation behaviors. However, difference $(\mathrm{P}<0.05)$ between most frequently behaviors expressed was observed (Table 3). Animals submitted exclusively to functional exercises increased ( $\mathrm{P}<$ 0.05 ) the frequency of lowering neck, exposing the penis, chewing and supporting on three limbs. When submitted to acupuncture alone, there was an increase in frequency of chewing and a reduction in the act of napping; while the combination of functional exercises and acupuncture promoted a higher frequency of chewing and body shaking, also reduced naps frequency.

Before the beginning of experimental treatments execution, same behavioral pattern $(\mathrm{P}>0.05)$ related to muscle relaxation was observed. After treatments application, differences $(\mathrm{P}<0.05)$ were observed for lowering neck, penis exposure and droopy ears, between treatments. Horses submitted just to functional exercises showed higher penis exposure and lowering neck frequencies. Finally, animals submitted to the combination of exercises and acupuncture, and only acupuncture treatments, performed chewing and lateral ears positioning behaviors more frequently (Table 4 ).

\section{DISCUSSION}

In this study, positive results were observed for muscle activation and animal relaxation degree, after performing experimental treatments. Increase in body surface temperature was observed in all evaluated regions after performing a single session of functional exercises, demonstrating that this activity is adequate to promote effective muscle activation, capable of upgrade worked muscles.

According to CAYADO et al. (2006); physical exercise, when performed properly and at ideal intensity, is capable of causing physiological stress in the body promoting the development of adaptation processes to this situation, stimulating muscle development over time. This physiological stress can be observed when local temperature increases and, therefore, when the opposite occurs, with no temperature increase, it is believed that the physical activity was not enough to work the muscle satisfactorily.

It is possible that body temperature increase occurred due to the considerable contraction intensity of muscle groups worked in each dynamic mobilization exercise. Muscles temperature increase

Table 1 - Arithmetic means and standard deviations of superficial skin temperature $\left({ }^{\circ} \mathrm{C}\right)$ in horses submitted to functional exercises and/or acupuncture (ACU)

\begin{tabular}{lccc}
\hline Treatments & Initial temperature & Final temperature & P-value \\
\hline Training & $33.47 \pm 0.02$ & $33.68 \pm 0.02$ & $<0.0001$ \\
Training + ACU & $34.20 \pm 0.3$ & $34.04 \pm 0,3$ & 0.5875 \\
ACU & $33.44 \pm 0.03$ & $33.44 \pm 0.03$ & 0.8403 \\
\hline
\end{tabular}

*Skin surface temperature mean values obtained every 30 seconds before and after experimental treatments. 
Table 2 - Arithmetic means and standard deviations for superficial skin temperature $\left({ }^{\circ} \mathrm{C}\right)$ of different animal regions in horses submitted to functional exercises and/or acupuncture (ACU).

\begin{tabular}{|c|c|c|c|c|}
\hline Treatments & Body region & $\mathrm{BT}^{1}$ & $\mathrm{AT}^{1}$ & p-value ${ }^{2}$ \\
\hline \multirow{5}{*}{ Training } & Cervical & $33.79 \pm 0.22$ & $34.00 \pm 0.22$ & $<0.0001$ \\
\hline & Thoracic & $33.62 \pm 0.21$ & $33.93 \pm 0.22$ & $<0.0001$ \\
\hline & Dorsal & $33.44 \pm 0.21$ & $33.55 \pm 0.22$ & 0.0108 \\
\hline & Abdominal & $33.26 \pm 0.22$ & $33.37 \pm 0.22$ & 0.0442 \\
\hline & Pelvic & $33.29 \pm 0.19$ & $33.55 \pm 0.22$ & $<0.0001$ \\
\hline \multirow{5}{*}{ Training + ACU } & Cervical & $34.24 \pm 0.24$ & $34.35 \pm 0.24$ & 0.0319 \\
\hline & Thoracic & $34.07 \pm 0.22$ & $34.13 \pm 0.22$ & 0.2134 \\
\hline & Dorsal & $33.82 \pm 0.26$ & $33.77 \pm 0.26$ & 0.2007 \\
\hline & Abdominal & $35.93 \pm 1.37$ & $33.48 \pm 0.98$ & 0.1399 \\
\hline & Pelvic & $33.62 \pm 0.78$ & $34.14 \pm 0.62$ & 0.5263 \\
\hline \multirow{5}{*}{$\mathrm{ACU}$} & Cervical & $33.81 \pm 0.33$ & $33.89 \pm 0.33$ & 0.2612 \\
\hline & Thoracic & $33.65 \pm 0.32$ & $33.75 \pm 0.31$ & 0.1089 \\
\hline & Dorsal & $33.36 \pm 0.36$ & $33.30 \pm 0.36$ & 0.2889 \\
\hline & Abdominal & $33.22 \pm 0.27$ & $33.10 \pm 0.27$ & 0.0707 \\
\hline & Pelvic & $33.17 \pm 0.29$ & $33.17 \pm 0.29$ & 0.9464 \\
\hline
\end{tabular}

${ }^{1}$ Average body temperature values obtained every 30 seconds before (BT) and after (AT) the beginning of the experimental treatments; ${ }^{2} \mathrm{P}$-value $<0.05$ differ with $\mathrm{F}$ test.

promotes greater performance, enabling oxygen release to erythrocytes with increase of thermoreceptors, leading to improve blood flow (SECANI \& LÉGA, 2009).

In the present study, the increase in muscle temperature may have been a consequence of increased ATP production and, subsequent, energy release in form of heat (ARAÚJO \& MENÓIA, 2008) as result of muscle stimulation, and physical efforts in response to functional exercises applied.
FERRAZ (2016) and OHMURA et al. (2021) inferred that skeletal muscle metabolism occurs as a direct source of energy from ATP production and, for this process to occur, the body needs energy. In muscle contraction processes each myosin filament binds to actin, and ATP is used to produce movement, resulting in muscle activation and energy release in form of heat, which may increase local temperature and still circulate through the body.

Table 3 - Behaviors expression related to muscle relaxation before (BT) and after (AT) beginning the execution of functional exercise program, with or without association to acupuncture (ACU).

\begin{tabular}{|c|c|c|c|c|c|c|}
\hline \multirow[t]{2}{*}{ Parameters (\%) } & \multicolumn{2}{|c|}{ 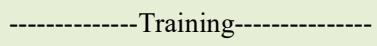 } & \multicolumn{2}{|c|}{---------Training +ACU------- } & \multicolumn{2}{|c|}{ - } \\
\hline & BT1 & AT1 & BT1 & AT1 & BT1 & AT1 \\
\hline Lowering neck & 12.50 & $20.42^{*}$ & 16.15 & 11.54 & 12.00 & 16.50 \\
\hline Penis exposure & 0.00 & $7.08^{*}$ & 0.00 & 1.54 & 2.00 & 0.50 \\
\hline Chewing & 3.33 & $16.25^{*}$ & 6.92 & $13.85^{*}$ & 6.00 & 23.50 \\
\hline Snort & 0.83 & 1.67 & 1.54 & 1.15 & 1.00 & 1.50 \\
\hline Nap & 0.00 & 1.25 & 4.62 & $0.00^{*}$ & 3.00 & $0.00^{*}$ \\
\hline Tree legs support & 21.67 & 31.25 & 23.85 & 31.54 & 27.00 & 31.50 \\
\hline Drooped ears & 19.17 & 20.00 & 36.92 & 32.31 & 40.00 & 32.50 \\
\hline Body shaking & 1.67 & 3.75 & 0.00 & $3.85^{*}$ & 1.00 & 5.00 \\
\hline
\end{tabular}

${ }^{1}$ Average frequency of behavior occurrence in horses, before (BT) and after (AT) treatments beginning; *Values on same line differ statistically by $\mathrm{F}$ test $(\mathrm{P}<0.05)$.

Ciência Rural, v.52, n.2, 2022. 
Table 4 - Behavioral characteristics occurrence in horses submitted to functional exercise program, with or without association to acupuncture (ACU).

\begin{tabular}{|c|c|c|c|c|}
\hline Parameters (\%) & Training & Training +ACU & Training & p-value \\
\hline Lowering neck & $20.42^{\mathrm{a}}$ & $11.54^{b}$ & $16.50^{\mathrm{a}, \mathrm{b}}$ & 0.0252 \\
\hline Penis exposure & $7.08^{a}$ & $1.54^{\mathrm{a}, \mathrm{b}}$ & $0.50^{\mathrm{b}}$ & 0.0001 \\
\hline Chewing & $16.25^{\mathrm{a}, \mathrm{b}}$ & $13.85^{b}$ & $23.50^{\mathrm{a}}$ & 0.0217 \\
\hline Snort & 1.67 & 1.15 & 1.50 & 0.8856 \\
\hline Nap & 1.25 & 0.00 & 0.00 & 0.0560 \\
\hline Tree legs support & 31.25 & 31.54 & 31.50 & 0.9973 \\
\hline Drooped ears & $20.00^{b}$ & $32.31^{\mathrm{a}}$ & $32.50^{\mathrm{a}}$ & 0.0025 \\
\hline Body shaking & 3.75 & 3.85 & 5.00 & 0.7710 \\
\hline
\end{tabular}

${ }^{*}$ Values with different letters on same line differ statistically by $\mathrm{F}$ test $(\mathrm{P}<0.05)$.

It is possible that activation of abdominal, dorsal and pelvic muscle regions occurred as result of chain muscle contraction, when there is an extensive combination of different muscle groups regarding to maintain the animal's posture, and balance, to assume a certain position for activity physics. Similar results were found by OLIVEIRA et al. (2015), who observed increase muscle activity in these regions, after ten minutes of exercise in the trotting guide in horses.

As previously mentioned, for horses submitted to the combination of functional exercises with acupuncture, increase in temperature was observed only in the cervical region. This may be linked to high activation of muscle groups in this region, confirmed by temperature increase even after waiting for 20 minutes necessary to complete acupuncture procedures.

In the case of animals submitted only to acupuncture, no increase in this procedure was observed in the studied regions $(\mathrm{P}>0.05)$. According to Aljobory (2017), the effect of acupuncture can vary according to the acupoint location according to the patient's individual characteristics, or to the method of inserting the needle into the acupoint (rotation or piston). Among many organism responses; increase, decrease or maintenance of the local body temperature can be observed.

There are a few ways to understand the acupuncture physiology after acupoint stimulation. One of them is the ability to release endorphins and opioids over peripheral nervous system, enabling to sends a message through neurotransmitters to the central nervous system (CNS). The CNS, similarly, will release the same substances and, via the bloodstream, they will be delivered to stimulated region (FARIA et al., 2008). Another way to understand the results of acupuncture was described by Aljobory (2017). This author alleged that, after needle insertion in the acupoints, there is a release of stagnant energy in the place, resulting in a slight change in temperature.

However, it is worth lay emphasis on acupuncture as a different mechanism of action that are still unknown, and may generate unexpected responses, especially in animals whose scientific works are even more scarce than in humans (LE JEUNE et al., 2016).

Conversely, an important innovation described in the present study was the adoption of a value of 0.8 for the emissivity of the skin of horses. The emissivity of this research differs from others in the literature, which use 0.95 as a reference value for horses, the same used for human skin (AUTIO et al., 2006). However, it is essential to determine the specific emissivity for each animal species due to their anatomical particularities, such as skin thickness (thinner in horses when compared to human skin), density and hair length (QUESADA, 2017).

When evaluating animal behavioral response, it was found that there was a higher frequency of behaviors related to relaxation in all treatments; however, behaviors expressed with greater frequency were different between treatments. Considering the time before and after treatments application, it can be argued that animals submitted to the functional exercises and with acupuncture, showed higher frequency executing lowered neck behavior, possibly due to intense activation of cervical region muscles, reported by temperature increase when compared to the other areas. 
In the case of penis exposure, which is more frequent in all treatments, it is possible that the activation of the abdominal muscles triggered this reflex. That is, these behavioral responses may be directly related to the activation and subsequent relaxation of muscle groups recruited during the performance of functional exercises.

Animals of all treatments showed higher frequency of chewing, a characteristic that can also be linked to peripheral nervous system response, related to well-being feeling (DYSON et al., 2017) induced by functional exercises and acupuncture.

The lowest frequency of nap behavior was observed in animals submitted exclusively to acupuncture and acupuncture and functional exercises treatments. In this case, it is possible that acupuncture may have promoted energetic clearance and increased blood flow over stimulated regions (ANGELI et al., 2007), relieving existing muscle tension points and causing the animals to become more active, as a result of greater physical relief in muscles worked. In fact, it is possible that animals were napping more often, not because they were sleepy, but as consequence of some muscle pain inducing the animal to remain longer instead of moving.

Similar results to those of the present study were reported by Angeli et al. (2007), where horses submitted to ten acupuncture sessions, revealed muscle pain disappearance, promoting the return or increase the animals' athletic performance.

Shaking body behavior can also be related to the increase in muscle stimulus, generated by physical activity and subsequent reduction in muscle tension because of acupuncture procedures. This causes the animal to demonstrate this behavior, in order to relieve body tension in whole body, indicating high degree of relaxation, absence of pain and greater physical comfort (VILLAS-BOAS et al., 2017; PEREIRA et al., 2018).

\section{CONCLUSION}

Perform a single session of dynamic mobilization exercises is adequate to promote muscle activation throughout the horse's body. In addition, both functional exercises and acupuncture, individually or in association, promoted muscle relaxation and interfere positively for animals' well-being.

\section{ACKNOWLEDGEMENTS}

The authors are grateful to the Coordenação de Aperfeiçoamento de Pessoal de Nível Superior (CAPES) - Brazil, financial code 001, and to the Mounted Police Squadron (EPMon) of the state of Sergipe for the invaluable support in making available the horses used in this study.

\section{DECLARATION OF CONFLICT OF INTEREST}

We have no conflict of interest to declare.

\section{AUTHORS' CONTRIBUTIONS}

All authors critically revised the manuscript and approved of the final version.

\section{BIOETHICS AND BIOSSECURITY COMMITTEE APPROVAL}

All experimental procedures were approved by the Ethics Committee on Animal Research of the Universidade Federal de Sergipe under the protocol no 05/2019.

\section{REFERENCES}

AUTIO, E. et al. Measuring the heat loss in horses in different seasons by infrared thermography. Journal of Applied Animal Welfare Science, v.9, p.211-221, 2006. Available from: <https:// doi.org/10.1207/s15327604jaws0903_3>. Accessed: Mar. 15, 2020. doi: 10.1207/s15327604jaws0903_3.

ANGELI, A. L. et al. Acupuncture applied to equine sports medicine. Revista Academica de Curitiba, v.5, n.3, p.325-333, 2007. Available from: <http://dx.doi.org/10.7213/cienciaanimal. v5i3.10146>. Accessed: Mar. 12, 2020. doi:10.7213/cienciaanimal. v5i3.10146.

ALJOBORY, A. M. I. S. Effectivness the acupuncture and electroacupuncture in the treatment of Delayed Onset Muscle Soreness in Racing Horses: Comparative Study. Kufa Journal For Veterinary Medical Sciences, v.8, n.1, p.109-119, 2017. Available from: <http://journals.uokufa.edu.iq/index.php/kjvs/ article/view/5997>. Accessed: Feb. 23, 2021.

ARAÚJO, A. P. S., MENÓIA, E. Atividade lipolítica Durante a Prática de Atividade Física: Enfoque Sobre o Consumo de Oxigênio, Produção de ATP e o Estímulo Neuro-Humoral. Revista Saúde e Pesquisa, v.1, n.2, p.177-184, 2008. Available from: $<$ https://periodicos.unicesumar.edu.br/index.php/saudpesq/article/ view/812>. Accessed: Mar. 12, 2020.

CAYADO, P. et al. Hormone response to training and competition in athletic horses. Equine Veterinary Journal, v.36, p.274-278, 2006. Available from: <https://beva.onlinelibrary.wiley.com/doi/ pdf/10.1111/j.2042-3306.2006.tb05552.x>. Accessed: Mar. 12, 2020. doi: 10.1111/j.2042-3306.2006.tb05552.x.

CLAYTON, H. M. et al. Dynamic mobilisations in cervical flexion: Effects on intervertebral angulations. Equine Veterinary Journal, v.42, p.688-694, 2010. Available from: $<$ https://doi.org/1 0.1111/j.2042-3306.2010.00196.x>. Accessed: Jul. 10, 2020. doi: 10.1111/j.2042-3306.2010.00196.x.

CLAYTON, H. M. et al. Center-of-pressure movements during equine-assisted activities. The American Journal of 
Occupational Therapy, v.65, p.211e6, 2011. Available from: $<$ https://doi.org/10.5014/AJOT.2011.000851>. Accessed from: Jul. 10, 2020. doi: 10.5014/AJOT.2011.000851.

CLAYTON, H. M. Core training and Rehabilitation in Horses. Veterinary Clinical Equine, v.32, p.49-71, 2016. Available from: $<$ https://doi.org/10.1016/j.cveq.2015.12.009>. Accessed from: Jul. 10, 2020. doi: 10.1016/j.cveq.2015.12.009.

D'ANGELIS, F. H. F. et al. Ultra-sonografia do músculo Longissimus dorsi de equinos da raça Puro-sangue Árabe em treinamento de resistência associado à suplementação prolongada com creatina. Revista Brasileira de Ciências Veterinária, v.12, p.142-146, 2004. Available from: <http://dx.doi.org/10.4322/ rbcv.2014.320>. Accessed from: Jul. 10, 2020. doi: 10.4322/ rbcv.2014.320.

DYSON, S. et al. Can the presence of musculoskeletal pain be determined from the facial expressions of ridden horses (FEReq)? Journal of Veterinary Behavior: Clinical Applications and Research, v,19, p.78-89, 2017. Available from: <http://dx.doi.org/ doi:10.1016/j.jveb.2017.03.005>. Accessed: Feb. 10, 2021. doi: 10.1016/j.jveb.2017.03.005.

DYSON, S. et al. Development of an ethogram for a pain scoring system in ridden horses and its application to determine the presence of musculoskeletal pain. Journal of Veterinary Behavior, v.23, p.47-57, 2018. Available from: <http://dx.doi. org/10.1016/j.jveb.2017.10.008>. Accessed: Feb. 10, 2021. doi: 10.1016/j.jveb.2017.10.008.

FARIA, A. B.; SCOGNAMILLO-SZABÓ, M. V. R. Acupuntura Veterinária: Conceitos e técnicas. ARS Veterinaria, v.24, n.2, p.83-91, 2008. Available from: <http://arsveterinaria.org.br/index. php/ars/article/view/184/152>. Accessed: Feb. 10, 2020.

FERRAZ, G. C. Fisiologia do exercício e performance equina. Revista Acadêmica de Ciência Equina, v.1, n.1, p.19-27, 2016. Available from: <http:/www.gege.agrarias.ufpr.br/grupeequi/ racequi/artigos/2016/fisiologia $\% 20$ do $\% 20$ exercicio.pdf $>$. Accessed: Mar. 12, 2020.

FREIRE, F. C. et al. Avaliação dos efeitos da acupuntura no IG4 (Hégu) por termografia de infravermelho. Pan American Journal of Medical Thermology, v.2, p.63-69, 2015. Available from: <http:// dx.doi.org/10.18073/2358-4696/pajmt.v2n2p63-69>. Accessed: Feb. 10, 2020. doi: 10.18073/2358-4696/pajmt.v2n2p63-69.

GLEERUP, K. B. et al. An equine pain face. Journal Veterinary Anaesthesia Analgesia, v. 42, p. 103-114, 2015. Available from: $<$ https://doi.org/10.1111/vaa.12212>. Accessed: Jul. 15, 2020. doi: $10.1111 /$ vaa. 12212 .

LE JEUNE, S. et al. Acupuncture and equine Rehabilitation. Veterinary Clinics of North America: Equine Practice, v. 32, n. 1, p. 73-85, 2016. Available from: <http://dx.doi.org/10.1016/j. cveq.2015.12.004>. Accessed: Feb. 24, 2021. doi: 10.1016/j. cveq.2015.12.004.

MONTANHOLI, Y. R. et al. Application of infrared thermography as an indicator heat and methane production and its use in the study of skin temperature in response to physiological events in dairy cattle (Bos Taurus). Journal of Thermal Biology, v.33, p.468-475, 2008. Available from: <https://doi.org/10.1016/j. jtherbio.2008.09.001>. Accessed: Jul. 10, 2020. doi: 10.1016/j. jtherbio.2008.09.001.
NELSON, D. L.; COX, M. M. Princípios de bioquímica de Lehninger. São Paulo: Artmed, 2014.

OLIVEIRA, K. et al. Gymnastic training and dynamic mobilization exercises improve stride quality and increase epaxial muscle size in therapy horses. Journal of Equine Veterinary Science, v.35, p.888-93, 2015. Available from: <http://dx.doi.org/10.1016/j. jevs.2015.08.006>. Accessed from: Jul. 10, 2020. doi: 10.1016/j. jevs.2015.08.006.

OLIVEIRA, K. et al. Gymnastic training of hippotherapy horses benefits gait quality when ridden by riders with different body weights. Journal of Equine Veterinary Science, v.1, n.94, p.103248, 2020. Available from: <https://dx.doi.org/10.1016/j. jevs.2020.103248>. Accessed from: Feb. 05, 2021. doi: 10.1016/j. jevs.2020.103248.

OHMURA, H. et al. Metabolomic analysis of skeletal muscle before and after strenuous exercise to fatigue. Scientific Reports, v.11, n.1, p.1-9, 2021. Available from: <https://dx.doi.org/10.1038/ s41598-021-90834-y>. Accessed from: June 05, 2021. doi: 10.1038/s41598-021-90834-y.

PELLEGRINI, D. Z. et al. Equine acupuncture methods and applications: A review. Equine Veterinary Education, v.35, n.5, p.268-277, 2018. Available from: <http://dx.doi.org/10.1111/ eve.12928>. Accessed: Feb. 24, 2021. doi: 10.1111/eve.12928.

PEREIRA, R. V. G. et al. Conditioning horse for maintenance in hippotherapy. Pubvet, v.12, n.6, p.1-5, 2018. Available from: $<$ https://doi.org/10.22256/pubvet.v12n6a106.1-5>. Accessed: Mar. 12, 2020. doi:10.22256/pubvet.v12n6a106.1-5.

QUESADA, J. I. P. Application of infrared thermography in sports Science. Espanha: Springer International Publishing, p.327, 2017.

RIZZO, M. et al. Cortisol levels and leukocyte population values in transported and exercised horses after acupuncture needle stimulation. Journal of Veterinary Behavior, v.18, p.56-61, 2017. Available from: <http://dx.doi.org/10.1016/j.jveb.2016.12.006>. Accessed: Feb. 05, 2021. doi: 10.1016/j.jveb.2016.12.006.

RODRIGUES, P. G. et al. Muscle and biomechanical response time in patrol horses submitted to functional training. Research, Society and Development, v.10, n.3, e26710313204, 2021. Available from: <http://dx.doi.org/10.33448/rsd-v10i3.13204>. Accessed from: Mar. 05, 2021. doi: 10.33448/rsd-v10i3.13204.

ROPKA-MOLIK, K. et al. Exercise-induced modification of the skeletal muscle transcriptome in Arabian horses. Physiological Genomics, v.49, p.318 -326, 2017. Available from: <http://dx.doi. org/10.1152/physiolgenomics.00130.2016>. Accessed: Feb. 05, 2021. doi: 10.1152/physiolgenomics.00130.2016.

SECANI, A.; LÉGA, E. Fisiologia do exercício em equinos. Nucleus Animalium, v.1, n.2, 2009. Available from: <http:// dx.doi.org/10.3738/1982.2278.282>. Accessed: Feb. 05, 2020. doi: $10.3738 / 1982.2278 .282$.

SOROKO, M. et al. Exercise-induces changes in skin temperature and blood parameters in horses. Archives Animal Breeding, v.62, p.205-213, 2019. Available from: <https://doi.org/10.5194/ aab-62-205-2019>. Accessed: Mar. 23, 2020. doi: 10.5194/aab62-205-2019. 
STUBBS, N. C. et al. Dynamic mobilization exercises increase cross sectional area of Musculus multifidus. Equine Veterinary Journal, v.43, n.5, p.522-529, 2011. Available from: <https://doi. org/10.1111/j.2042-3306.2010.00322.x>. Accessed: Jul. 10, 2020. doi: $10.1111 / \mathrm{j} .2042-3306.2010 .00322 . x$.

TABOR, G. The effect of dynamic mobilization exercises on the equine multifidus muscle and thoracic profile. Plymouth: Universidade de Plymouth, 2015.
VILLAS-BOAS, J. D. et al. Effect of acupuncture on stress responses in equine athletes submitted to dressage. Brazilian Journal of Veterinary Medicine, v.34, n.4, p.221-230, 2017. Available from: <https://doi.org/10.29374/2527-2179. bjvm020517> Accessed: Mar. 12, 2020. doi: 10.29374/25272179.bjvm020517.

XIE, H.; PREAST, V. Acupuntura Veterinária Xie. São Paulo: MedVet., 2011. 